\title{
Solomon Rises to the Throne
}

\author{
8.1 I Kings 1:1-53
}

\subsubsection{Kings 1:1-4}

At the lower level of the narrative it is stated that King David was old and that he could not get warm (1:1). David's servants suggest to David that they find a young virgin to wait on the king, to be his attendant, and to lie in his bosom in order to keep him warm (1:2). The servants search for a beautiful girl and find Abishag the Shunammite who they present to the king (1:3). It is remarked that the girl was very beautiful and that she became the king's attendant but that the king did not know her (1:4). At the upper level of the narrative it is implied that the great lady's man, David, is feeble and impotent. This kind of ridicule is consistent with the genre of satire even though it is unacceptable in many quarters of today's civil society to make fun of a person's advanced age and sexual dysfunction. Indeed, this form of ridicule is, according to Muecke, irony in the style of burlesque. In this style of irony a high character is presented in a lowly way. Thus, the most powerful man in Israel is presented as being without power. This is the conflict in the narrative between the upper (implicit) and lower (explicit) levels.

The innocence is the feigned innocence of the ironist. King David is the object of ironic attack as it is his character that is being ridiculed and diminished. The mode of irony is impersonal irony and the sub-category of irony is burlesque as already noted. The irony is covert and is conveyed in part by anomalies in the language. Saliently, we find here an example of Perry and Sternberg's verbose/concise pattern. In this instance, $1: 1-4 b$ is the verbose section. This passage is replete with sexual language. A young virgin is sought, although she was to attend to the king it could be assumed that her primary role was to serve David sexually (1:2). This is expressed in the following innuendo:

ושכבה בחיקך והם לאדני המלך (1:2)

(... let her lie in your bosom, that my lord the king may be warm). ${ }^{1}$

1 Translation from Rsv. 
To "lie in your bosom" implies sexual activity. ${ }^{2}$ Verse 1:2 mentions all of the activities that the young virgin will carry out for King David, but the emphasis is on her proposed sexual service to the king. This emphasis is stressed in the commentary that the servants looked for "a beautiful girl" (1:3) and that they found "a very beautiful girl" (1:4). Therefore, it would seem that the servants were preoccupied with finding a girl with remarkable physical attributes rather than a girl with remarkable skills as a servant. The stress on her beauty heightens the ridicule of David, as does the following concise remark that implies that David could not perform sexually with the very beautiful girl:

(... but the king did not know her). ${ }^{3}$

והמלך לא ידעה (1:4)

\subsubsection{Kings 1:5-10}

At the lower level of the narrative Adonijah declares that he will be king and prepares chariots, horsemen, and fifty men to accompany him (1:5). It is stated that at no time did David question Adonijah's behaviour. It also stated that he was handsome and born after Absalom (1:6). Adonijah conferred with Joab and Abiathar who supported him (1:7). At the upper level of the narrative the ironist implies that Adonijah should have rightly been the next in line to the throne. This implication arises with knowledge of the three qualities mentioned in verse 1:6 that are as follows: (1) Adonijah's behaviour was impeccable according to David (possibly even in this instance David had no reason to object to Adonijah's preparations to be king); (2) he was handsome (a standard measure of one's worthiness to be king); and (3) he was born after Absalom and next in line to the throne (assuming Chilead had died). This last point would seem to contradict the argument that primogeniture was not established at this time, ${ }^{4}$ or at the very least it would seem to contradict the argument that the order of birth was not a consideration for succession. Indeed, being handsome was thought to signify that God had graced an individual so it would follow that birth order would also be deemed an act of God. Furthermore, Solomon's later statement "Ask for him the kingdom as well! For he is my elder brother ..." (I Kgs. 2:22) would suggest that it was standard practice for the eldest son to inherit the king's throne. Accordingly, while the narrative does not explicitly mention that Adonijah was rightly in line to the throne, this is implied. For

2 Mordechai Cogan, I Kings (New Haven: Yale University Press, 2008), 156.

3 Translation NKJ.

4 Jerome T. Walsh, Berit Olam. Studies in Hebrew Narrative and Poetry. I Kings, (Collegeville: Liturgical Press, 1996), 6. 
the mention of the three significant determinates of kingship are presented without further commentary, thereby implying that Adonijah was the rightful heir to the throne.

The conflict in the narrative is heightened by the matter-of-fact presentation of facts. This presentation is incongruent with the loaded message they intend to convey - that Adonijah should have been the rightful king. Moreover, contrary to commentaries that suggest that Adonijah's actions are unacceptable and that his good character is questionable, ${ }^{5}$ Adonijah's actions may have been the morally correct actions to take, given David's infirmity. This would certainly be consistent with the comment in 1:6 that David never had reason to question Adonijah's actions. Therefore, the extra pronoun in 1:5 (אני אמלך), that is so often interpreted as an indicator of Adonijah's vanity, ${ }^{6}$ could also indicate resolve. After all, King David was aged and bedridden (I Kgs. 1:1-5). This left Israel in a supremely vulnerable position. It would have been honourable for somebody to prepare for the role of the king. Moreover, it would seem natural that Adonijah would assume that this was to be his role. It is also worth noting in the narrative that at this point Adonijah merely says "I will be king" (1:5) not that he was king.

The irony in this instance is covert and impersonal. The sub-category of impersonal irony is innuendo. The innuendo is that Adonijah is the rightful heir to the throne.

\subsubsection{Kings 1:11-35}

At the lower level of this narrative Nathan and Bathsheba ensure that Solomon becomes the King of Israel. To be specific, Nathan tells Bathsheba to go into David and to say to him (ask him) if it was the case that David swore to Bathsheba that he would make Solomon the king (1:13). Nathan tells Bathsheba that he will come to David while she is talking to him and confirm what she says (1:14). Bathsheba does as Nathan instructs her (1:15-21). Nathan goes to David and confirms what Bathsheba says, as planned, albeit apparently in the absence of Bathsheba (1:22-27). Later on King David summons Bathsheba (1:28) and David swears that Solomon will become the next king (1:29-30). Bathsheba does obeisance to David (1:31). David summons Zadok, Nathan, and Benaiah (1:32) and tells them to take Solomon to Gihon and to anoint him (1:33-35).

5 Marvin Sweeney, I \& II Kings (London: Westminster John Knox Press, 2007), 54.

6 Ibid. 
The possible implications at the upper level vary depending on whether or not David made an oath to make Solomon king and whether or not Adonijah had been anointed king - matters about which there is uncertainty. What we do know is that Adonijah was preparing to be king. The following discussion will consider all of these options. In the first instance let us assume that David did not make an oath. If this is the case then Nathan and Bathsheba are lying and trying to trick David. In doing so they would be relying on his senility and his consequent inability to remember if he made an oath or not.

Most commentators favour this option. Take for example Martin Mulders following comment: "The author suggests that David, old and senile, not only remembers nothing of what he might possibly have promised at some time in the past, but is also very amenable to being influenced. This is the circumstance which Nathan and Bathsheba exploits." ${ }^{7}$ However, this argument is somewhat contradicted by the presentation of David's rather lucid state in 1:28-35. In Jerome Walsh's words, "The figure of David undergoes a startling transformation in these two scenes. In place of the feeble, passive, even unresponsive old man of the first half of the story, we witness a determined figure, able to make a firm decision and act unhesitatingly on it. Whatever the king's physical frailties, he is clearly in control of his mental faculties." ${ }^{8}$ Furthermore, in order to accept the proposition that Nathan and Bathsheba are tricking David the reader must accept that Nathan, the holy prophet who chided David in 2 Samuel 12:7-12, is corrupt and irreligious. Surely, it is of poor faith for a religious man to lie to a dying man about an oath that he did not make to God!

It has been argued that Nathan's potentially corrupt character is the reason that his role as prophet is stressed so emphatically. For instance, instead of calling Nathan simply by his name, as is the narrator's usual choice, Nathan is spoken of as "Nathan the prophet". Walsh argues that the reason for this anomaly in the language is to remind the reader that the 'schemer' is also the prophet. ${ }^{9}$ It may, of course, be true that Nathan's role as prophet is stressed to emphasize this potentially grievous transgression, but it may also be the case that Nathan's role as a prophet is being stressed in order to suggest to the reader that Nathan must enforce religious law.

If it is the case that Nathan and Bathsheba are lying to David about an oath he made, but David cannot remember if he made an oath or not because of dementia, then the irony in this section is burlesque. In this scenario David, as

7 Martin J Mulder, I Kings (Leuven: Peeters, 1998) 54-55.

8 Jerome T Walsh, I Kings, 24.

9 Jerome T. Walsh, I Kings, 10. 
a high character is ridiculed as he cannot even remember if he made an oath or not. It would seem cruel to make fun of a person with dementia; however, this is in keeping with satirical writing.

The second scenario is as follows. David did make an oath (presumably sometime in the past) to make Solomon the king and is now in an invidious position because he is not objecting to Adonijah's preparations to become king (1:6). If this is the case, then Nathan and Bathsheba's manipulations are in the service of ensuring that David endorses Solomon as his successor over Adonijah. It could then be assumed that Bathsheba's motive is to ensure that her son, Solomon, becomes king as was promised. Nathan's motive is to ensure that an oath to God is honoured. This is understandable given his role as prophet and religious enforcer, so to speak. However, it still remains the case that arguably David was not entitled to make an oath to make Solomon king, given that Solomon was not next in line to be king. This difficulty remains regardless of whether or not Nathan and Bathsheba are lying to David and whether or not David re-states the oath he made or makes an oath for the first time in 1:29-30.

If we accept that David did make an oath to make Solomon king, there are a further two possible scenarios concerning Adonijah's actions: (1) David made an oath to make Solomon king but Adonijah has been inaugurated as king by the people (and, presumably, anointed as king by a priest), and (2) David made an oath to Solomon and Adonijah is merely preparing to be king (but is, as yet, not anointed).

In the first instance, Nathan and Bathsheba's intentions would seem to be reasonable. Bathsheba is making the case for her son, Solomon, who has a claim to the throne- by virtue of the king's oath. Nathan is ensuring that an oath to God (by David to Solomon) is being honoured. There is no irony in this scenario as it would appear to be a straight-forward rendering of events.

As far as the second situation is concerned-that Adonijah has not been inaugurated (or, therefore, anointed) as king - there are two strong possibilities: (1) Nathan and Bathsheba are outright lying to David concerning Adonijah's anointment, and; (2) Nathan and Bathsheba are exaggerating or overstating events for effect. The narrative allows for both interpretations. Consider the following uncertainties in the text. (i) Nathan tells Bathsheba and David that Adonijah has become king, Bathsheba repeats this to David (1:11, 18). However, the narrative otherwise only tells us that Adonijah said he will become king (1:5); (ii) It is unclear if the festival at En-rogel is an anointing or not (1:9). Both Bathsheba and Nathan interpret it this way $(1: 19 ; 25)$. However, Nathan and Bathsheba tell David that the sacrifices have been made in abundance (a sign 
of an anointing) (1:19, 25), when there is no other evidence of this in the narrative. Furthermore, Nathan tells David that Adonijah's invited guests are all exclaiming "Long live King Adonijah!" although there is no evidence of this beside Nathan's word (1:25).

If Nathan and Bathsheba are wilfully depicting Adonijah as being treasonous (in Adonijah claiming to be king while David is still alive) when he is not being treasonous, then both Nathan and Bathsheba are guilty of a serious transgression, namely, falsely accusing someone of treason. If Nathan and Bathsheba are engaging in this deceit they are presumably motivated by the desire to ensure that Solomon is made king. They intend to cause David to be angry with Adonijah and reject him as king. If so this could signify a corruption of, particularly, Nathan's character. In this instance, Nathan is described in the same terms as Joab and Absalom who were both depicted as characters who were displeased with David's rule and who tried to manipulate him in order to achieve a, presumably, more righteous outcome. Yet, in both instances we witness the decline of the moral fibre of these characters in their supposed zeal for righteousness. In the case of Joab, he would appear to be critical of David's corruption in the story of Uriah (2 Sam. 11:19-21). However, Joab is later depicted throughout the narrative as a character who takes the law into his own hands (2 Sam. 18:14; 20:10). Absalom is similarly critical of David's inability to administer justice (2 Sam. 15:3), but also descends into an unsuccessful vigilante character who also takes the law into his own hands by creating an insurrection against David, the rightful king (2 Sam. 15:1-6). Presumably, Absalom's desire to mete our justice against Amnon is his reason for manipulating David in 2 Samuel 14:2-21.

The irony here may be spoken of as impersonal irony with the sub-category of pretended defence of the victim. David is being tricked and manipulated and the reader is inclined to defend David. However, when the content of the narrative is considered comprehensively it appears that David is the fool and the victim of the irony as a reasonable person would not be expected to be in David's position, ie. supporting two sons to be king.

However, another possibility is that Nathan and Bathsheba are both presented as overstating Adonijah's royal pretensions. In this manner they are presenting a reasonable argument in a presumptive manner. It may seem evident to Nathan and Bathsheba that Adonijah's actions, amidst his preparations to become king, could be interpreted as furthering his ambitions to be king.

Either way we are still left with the knowledge that David has made an oath to one prince and has not objected to another prince's preparations to become king. Therefore, we have an example of another instance where David acts 
foolishly and puts the security of Israel at risk. David is also the object of ironic attack as his foolishness has serious implications for Israel and for the supporters of each son—as they will potentially be killed.

\subsubsection{Kings 1:36-37}

At the lower level of the narrative Benaiah answers David in the following way: "Amen! May the Lord, the God of my lord the king, so ordain (1:36)". Benaiah then goes on to wish that Solomon's throne is greater than King David's (1:37). At the upper level of the narrative is the implication that this appointment has not been ordained by God but has instead been decided by David. For instance,

Benaiah continues with what is probably a wish: "May Yahweh ordain ...," though the Hebrew can be understood as a simple statement of fact expressing Benaiah's confidence in the rightness of David's decision: "Yahweh will ordain ..." Like Bathsheba in verse 17, he relates Yahweh directly to David ("the God of my lord the king") rather than to the whole people as David did. This may be standard court flattery, but it also reflects an aggrandizement of the intermediary role of the king that is not fully compatible with the thinking of pre-monarchic Yahwism. If his words are understood as a statement rather than as a wish, the aggrandizement is extreme: the king has said it, therefore God wills it. ${ }^{10}$

The conflict in the narrative, is therefore, an opposition. At the lower explicit level Benaiah wishes that God will ordain this decision, yet, at the upper level it is implied that this decision is not God ordained. Benaiah is the unknowing victim of the irony as he is confidently unaware of the implications of his comment. David is the object of ironic attack as he has decided who the next king will be without due consideration of the elements that indicate that a candidate is endorsed by God, ie. birth order and attractiveness-elements that are beyond human control. The irony is impersonal and is an example of pretended agreement with the victim. In this instance, the narrative endorses Benaiah's exclamation at the lower level, but it is only pretended agreement at the upper level of the narrative.

The irony is covert as it is not immediately apparent and must be discerned by the language and background knowledge of the text. In this case the primary knowledge that informs the irony is the knowledge that kings are anointed by the people (2 Sam. 2:4; 5:3; 2 Kgs. 11:12; 23:30) or by Yahweh (1 Sam. 9:16; 10:1; 15:17; 16:12-13; 2 Sam. 12:7; 2 Kgs 9:36) — and not by the king.

$10 \quad$ Jerome T. Walsh, I Kings, 24. 


\subsection{Kings 2:1-46}

\subsubsection{Kings 2:1-9}

At the lower level of the narrative David talks to Solomon as David nears death (2:1). He tells Solomon that he is about to die (2:2) and instructs Solomon to keep all of the Lord's statutes, ordinances, testimonies, and commandments as they are written in the Law of Moses (2:3). David tells Solomon that God promised him that if his heirs were faithful to God there would always be a successor to David on the throne (2:4). David then reminds Solomon of what Joab did to him (by killing Abner and Amasa in peacetime, thereby putting Israel in jeopardy) and he suggests to Solomon that he deal with Joab and ensure that Joab does not go to Sheol (the afterlife) in peace (2:5-6). Furthermore, David instructs Solomon to deal loyally with the sons of Barzillai (2:7). Finally, David tells Solomon to send Shimei to Sheol in blood $(2: 8-9)$.

At the upper level of the narrative is the implication that David is largely disinterested in the laws, but is more concerned with settling scores. Walsh argues that this passage has more in line with opportunism than deuteronomistic morality.

David may use deuteronomistic language for purposes quite different from a deuteronomistic theologian. Here, for example, David is in the process of giving Solomon his final advice, one king to another, on how to ensure his success. But David's suggestions are made by innuendo, indicated by oblique references like "act according to wisdom" (v.6) and "you are a wise man; you will know what to do" (v.9). David expects Solomon to be shrewd enough to read between the lines of his advice. The deuteronomistic platitudes in verses $2-4$ function much like the references to wisdom. Solomon is to hear both platitudes and pragmatism and to read between the lines: "Obey the law (you know what I mean) and make sure you protect yourself from your enemies".11

David is, therefore, the object of ironic attack and the unknowing victim of this irony. He is the victim in as much as he is unaware of the religious offence in his statement. He is the object of ironic attack in as much as his comment is a further indication of his corrupt nature and disregard for the sacredness of the laws.

The mode of irony in this instance is impersonal irony and the sub-category of irony is parody. David's 'testament' is a parody of the idea that kings are

11 Jerome T. Walsh, I Kings, 38-39. 
morally upright and obedient to the laws. Please see Deuteronomy 31-33, Joshua 23-24 and 1 Samuel 12. I note that Deuteronomy 17:17-20 outlines that a king should be committed to justice. By contrast, David's proposed actions are unjust. The grade of irony is covert as it is not immediately apparent and is discerned in part by way of an appreciation of the anomalies in the language and the background history of the story. As far the tone of the language is concerned there is a jarring difference between the language in 2:1-4 (that appears to be noble) and the following passage $2: 5^{-9}$ (that appears to be self-serving). Furthermore, the background knowledge of the narrative suggests that David's decisions are not based on just judgements but are instead calculated to ensure that his legacy survives untainted. Consider the following examples.

The first-person David mentions to Solomon is Joab. David says to Solomon that Joab killed Abner and Amasa in peacetime to avenge blood that had been shed in war (2:5). Of note is David's following comment in 2:5:

וגם אתה ידעת את אשר־עשה יואב בן־צרויה

(You know too what Joab son of Zeruiah did to me .... $)^{12}$

However, this comment requires further discussion. There is some ambiguity concering Joab's motives for killing Abner and Amasa. It is possible that Joab had dual motives for killing Abner- to avenge his brother's death (2 Sam. 3:30) and to protect David from a potential threat (2 Sam. 3:24-25). The text offers both scenarios. The narrative also allows for numerous ironies which complicate an interpretation of this story. However, regardless of Joab's motives the explicit level of the text claims that Joab was not aware of Abner's private dealings with David. This would suggest that, in killing Abner, Joab is loyal to David. The situation with Amasa is similarly ambiguous. In 2 Samuel 17:25 it is clearly argued that Amasa is the commander in charge of the army who lead Absalom's revolt. In 2 Samuel 20:5 there is an implication that Amasa is a traitor as he takes a long time to immobilize an army against Sheba's rebellion. Thereby, leaving David vulnerable to Sheba's attack. When both of these scenarios are considered together-that of Amasa being the commander of Absalom's revolt against David and his delay in mobilizing an army to fight Sheba's rebellion against David—it would seem that David should be, at the very least, suspicious of Amasa.

Therefore, it is highly possible that Joab protected David from two army commanders who were traitors ( 2 Sam. $3: 24-25 ; 17: 25 ; 20: 5)$. At the very least, 
Joab's motives may be to do what is in the best interests of David. It may also be the case that to do what is in the best interests for David may also be in the best interests for Joab. This is consistent with Joab's motives throughout the SN in which Joab is inclined to do what is in the best interests for David's kingdomsometimes in spite of David's foolishness. The implication that Joab is treated unfairly by David is heightened in the contrast with David's partial treatment of Barzillai. Certainly, Barzillai treated David loyally when he was in need by providing David with food (2:7), but David appears to be oblivious to the fact that it was Joab's act of killing Absalom (2 Sam. 18:14) that ended Absalom's revolt and saved David's life. Thus, we have three instances where Absalom has saved David from traitors (or in the case of Abner and Amasa, probable traitors).

The inclusion of Shimei suggests that there is a further dimension in David's testimony, namely, that David is concerned to ensure that Solomon's kingship is not called into question and that David's own legacy is not compromised. In particular, David is worried that it could become common knowledge that he, David, usurped the throne of Saul by recourse to murder and that, therefore, David's anointment as king was not the result of God's will. If this did become common knowledge then Solomon's right to the throne would be called into question. Since Shimei and Joab are in possession of this potentially dangerous knowledge, the implication is that David is advising Solomon to kill them. Therefore, this passage is best understood as David's instruction to Solomon to get rid of potential threats rather than as an instruction to follow the laws.

\subsubsection{Kings 2:15-17}

At the lower level Adonijah tells Bathsheba that she knew the kingdom was his, and that Israel expected him to reign. Furthermore, he tells Bathsheba that the kingdom has turned about and become his brother's (i.e. Solomon's) for it is the will of the Lord (2:15). Adonijah then requests that Bathsheba ask Solomon to give Abishag to Adonijah as his wife. Bathsheba agrees to speak to Solomon on Adonijah's behalf (2:16). At the upper level of the narrative the ironist, in the person of Adonijah, implies that he knows that Solomon's rise to the throne was not the will of the Lord but rather as a result of Bathsheba' scheming. The conflict is a direct opposition in the narrative. Adonijah says that he knows that Solomon attained the throne by the Lord, however, the message that is conveyed is that he knows that the Lord did not make Solomon king. The innocence in the narrative is the feigned ignorance of Adonijah. The object of ironic attack is Solomon's illegitimate or, at least, premature rise to the throne.

The grade of irony is covert and the mode of irony is impersonal. The subcategory of impersonal irony is pretended error of ignorance. Adonijah pretends that Solomon's claim to the throne was the Lord's making. The irony is 
detected in part by means of the language and the narrative context. As far as the language is concerned there are three main stages in Adonijah's comment which are as follows:

(1) Adonijah clearly indicates that he believes that the kingdom was rightly his.

ויאמר את ידעת כי־לי היתה המלוכה ועלי שמו כל-ישראל פניהם למלך (2:15a) (He said, "You know that the kingdom was mine, and that all Israel expected me to reign .... $)^{13}$

(2) Adonijah dissimulates and pretends that this was the working of the Lord whilst implying that he knows that Bathsheba is behind this.

ותסב המלוכה ותהי לאחי כי מיהוה היתה לו (2:15b) (However, the kingdom has been turned over, and has become my brother's; for it was his from the LORD). ${ }^{14}$

(3) Adonijah requests that Bathsheba grant him his wish following on from his implicit message that he knows that Bathsheba was behind Solomon's enthronement. In other words, the implied message is, "I know that you are behind Solomon stealing the throne from me, therefore, the least you can do is fulfil my request."

ועתה שאלה אחת אנכי שאל מאתך אל־תשבי את־פני (2:16) (And now I am making one request of you; do not refuse me). ${ }^{15}$

The context clearly points to irony because Adonijah's actions are inconsistent with the explicit information in the narrative. To be more specific, Adonijah says that he knows that Solomon's rise to the throne was the work of the Lord, yet he is clearly trying to challenge the throne by taking the king's concubine (2:17). This would seem to discount the explicit text that Adonijah was accepting of Solomon's, supposedly, divinely appointed kingship.

\subsubsection{Kings 2:19-25}

At the lower level of the narrative Bathsheba goes to speak to Solomon on behalf of Adonijah and tells him that she has one small request (2:19-20a).

13 Translation from the NRS.
14 Translation from the NKJ.
15 Translation from the NAS. 
Solomon tells Bathsheba to make her request (2:2ob). Bathsheba tells Solomon to give Abishag to Adonijah to be his wife (2:21). Solomon answers Bathsheba with the question, why does she ask this question, and why does she not ask for the kingdom for Adonijah? Solomon tells Bathsheba that Adonijah is his elder brother and says that she should ask for the kingdom for Adonijah on behalf of Zeruiah and Joab also (2:22). Solomon then swears on the Lord who has established him as king that Adonijah should be put to death (2:23-24). In verse 25 Benaiah kills Adonijah.

At the upper level of the narrative the implication is that Bathsheba's 'small' request is in fact a 'large' request. This is a direct opposition in the narrative that is largely confirmed by Solomon's anger.

Solomon immediately sees through Bathsheba's question and Adonijah's intention. He latches onto the 'small' request-Abishag as wife for Adonijah - by asking why Bathsheba does not immediately come up with the 'big' request: the kingship for Adonijah! The ו before למה, according to Burney, has a sarcastic nuance. The same is true for the $\mathrm{I}$ before the imperative שאלי, which conveys an aspect of irony. ${ }^{16}$

However, despite Solomon's shrewdness Solomon is the victim of irony as he gives reason why Adonijah should be king, notably because he is the elder brother (2:22), but then claims that his own kingship is the work of God (2:24). This kingship he begins with a contentious homicide. The irony in Bathsheba's comment and in Solomon's foolishness is innuendo. Therefore, the irony is covert and impersonal.

\subsubsection{Kings 2:26-27}

At the lower level of the narrative Solomon tells Abiathar that he deserves death but that he will not be put to death because he carried the ark and shared in David's hardships (2:26). Solomon stops Abiathar from being a priest (2:27). At the upper level of the narrative the ironist implies that Abiathar does not deserve death. This can be concluded because he merely endorsed the rightful heir to the throne, who did not meet any objections from David as he was preparing to be king (1:6). Therefore, the conflict in the narrative is a direct opposition. The mode of irony is impersonal and the sub-category of irony is Blaming in Order to Praise-(c) Inappropriate or irrelevant praise. In this manner the ironist, as the narrator of the story, blames Abiathar for supporting Adonijah (I Kgs. 2:26). This is inappropriate blame as Adonijah was the rightful heir to 
the throne. Furthermore, Abiathar is praised for his loyalty to David. This is irrelevant praise as the reason that Abiathar deserves to live is not because of his loyalty to David but instead because of his loyalty to the rightful King of Israel.

The narrator's mention of Abiathar's banishment as the fulfilment of the Lord's word to the house of Eli in Shiloh (2:27) is a further intentional untruth. Abiathar is a descendant of the priests of Nob, not the priests of Eli. ${ }^{17}$ Thus the narrator, with a wink, suggests that Abiathar's exile is lawful and God ordained, when this could not be further from the truth. Instead, the truth in the narrative is that Solomon is corrupt and a dangerous and unjust despot. The grade of irony is covert and is discerned according to the background knowledge of the text.

\subsubsection{Kings 2:28-35}

At the lower level of the narrative Joab learns of Abiathar's expulsion and flees to the Lord's tent and grabs the horns of the altar (2:28). By convention, the significance of Joab grabbing the horns of the altar is that Joab is publically declaring his innocence and, in effect, calling for some formal process of adjudication. Moreover, Solomon ought to respect this convention, especially in cases where there is some doubt as to the guilt of the complainant, as there is with Joab. However, when Solomon is told that Joab has fled to the tent and is beside the altar holding its horns, Solomon orders Benaiah to kill him (2:29). Benaiah tells Joab that Solomon has commanded Joab to come out of the tent. Joab refuses to do so and tells Benaiah to kill him in the tent and Benaiah conveys this information to Solomon (2:30). Solomon now orders Benaiah to kill Joab at the altar to remove bloodguilt from the House of David (2:31). Solomon then goes on to say that Joab killed Abner and Amasa without David's knowledge (2:32). Benaiah kills Joab and is made general in Joab's place (2:34-35).

At the upper level of the narrative the ironist implies that it is Solomon who has blood on his head for the execution of Joab at the holy altar despite the insistence in the narrative that it is Joab who has guilt on his head (2:32-33). This is because Solomon refused to adhere to the convention to have Joab's actions formally adjudicated and, thereby, raised the suspicion that if there had been a judicial process Joab would not have been found guilty. As discussed previously, it would appear that Joab had some reason to believe that Abner and Amasa were both traitors. Therefore, the conflict in the narrative is a direct opposition. On the one hand, Solomon kills Joab ostensibly to remove bloodguilt from the House of David (2:32). On the other hand, in ordering Joab's execution at the holy altar without affording him due process, Soloman has

Volkmar Fritz, 1 \& 2 Kings, 29. 
defiled the altar, acted unjustly and, indeed, corruptly. His corruption consists in violating an important convention that serves justice and doing so out of self-interest. Therefore, Solomon brings bloodguilt onto the House of David in an unmitigated way.

The ironic content arises from the striking contrast between Solomon's emphatic announcement of the righteousness of his actions carried out with the purest of motives (to preserve the House of David) and the fact that his actions are unjust and probably motivated by self-interest. Here Solomon is obviously the object of ironic attack. Solomon is also the unknowing victim of irony in this passage as he is oblivious to the great offense he has committed against God and Israel. The mode of irony is impersonal. Furthermore, the sub-category of impersonal irony is irony displayed as the pejorative criticism of Solomon is conveyed by way of the ordering of the events (and the close confrontation of incompatibles). The grade of irony is covert as discerning the irony relies in part on background knowledge of the narrative. In particular, the background knowledge facilates our grasp of two major inconsistencies in the narrative: (1) Joab's loyalty to the House of David and Solomon's killing of Joab allegedly for treason, and (2) Solomon's supposedly sincere desire to free the House of David from bloodguilt, whilst ordering a profane and unjust act at the altar of God. ${ }^{18}$

As far as Joab's loyalty is concerned, Walsh argues, "The remark that Joab supported Adonijah but not Absalom reminds us that Joab's loyalty to David was unbroken, even during Absalom's rebellion ... and Joab's support of the heir apparent simply continued his loyalty to the dynasty."19 I have also argued that Joab's support of Adonijah was a display of support for the rightful heir of David. Therefore, Solomon's order for Benaiah to kill Joab is as unjust as David's order for Joab to instigate Uriah's death, and Absalom's order for his men to kill Amnon. This unjust killing of Joab, therefore, is a continuation of the series of unjust and unlawful acts in the House of David. Thus, by the end of the SN the abuse of authority by those within the monarchy is conclusively established and, indeed, is set to continue.

\subsubsection{Summary of Irony in I Kings 1:1-2:46}

David is ridiculed in a burlesque style of irony in I Kgs 1:1-4. There it is implied that he is impotent and powerless. In the following passage (I Kgs. 1:5-10) it is implied in an innuendo that Adonijah is the rightful heir to the throne. In I Kings 1:11-35 David is the object of ironic attack as it becomes apparent

18 Jerome T. Walsh, I Kings, 57.

19 Ibid. 
that he is the reason that Solomon becomes the next king despite the knowledge that Adonijah is the rightful heir to the throne. Indeed, the ironic criticism in this passage is that David swears an oath that one son can be the king whilst not objecting to the preparations of another entitled son to be the king. In I Kings 1:36-37 there is an example of the ironic category of pretended agreement with the victim. Benaiah wishes that the decision for Solomon to be king be God-ordained while the ironist implies that the decision is not God-ordained. Far from it, David has decided who will be the succeeding king in the most unjust manner. In I Kings 2:1-9 David's 'testament' to Solomon is a parody of the idea that kings are righteous and obedient to the laws. In contrast to this David's 'testament' urges Solomon to break the law to settle David's scores and protect David's dynasty (including Solomon's kingship). The irony in I Kings 2:15-17, which is the pretended error of ignorance further implies that Adonijah is the rightful heir to the throne. This theme is continued in the form of an innuendo in I Kings 2:19-25. There Solomon himself implies that Adonijah is the rightful heir to the throne. The criticism continues in I Kings 2:26-27 when Solomon ruthlessly tells Abiathar that he deserves death when there is no justifiable reason in the narrative to support this claim. The irony in this instance is irrelevant or inappropriate praise. The irony in this chapter, and indeed the SN, concludes with unmitigated criticism of Solomon. In this section Solomon orders the unjust killing of Joab at the altar of God. This criticism is implied by way of irony displayed. 